\title{
Curriculum Model to Ensure Personnel-Training Platform of Adapt to Energy- Saving and Emission-Reduction
}

\author{
Xingjia LIU,Jiuru LI,Wei LV,Zuomin WANG,Mingqi SUN \\ Department of Thermal Energy and Power Engineering \\ Harbin University of Science and Technology \\ Harbin, China \\ xj3333333@sina.com
}

\begin{abstract}
In view of the needs of higher education personnel training in condition of low-carbon economy, this paper analyzes the importance to reform the higher-education personnel-training model in competition; researches the difficulties of the wide caliber personnel-training and the relationship between the wide caliber and insisting characteristics ; discusses the requirements of the scientific curriculum system and its influencing factors; expounds the role of establishing characteristic curriculum system in the professional personnel-training; puts forward to the contents and model of construction of the curriculum system which has wide caliber and feature and adapts to personnel-training of Energy-Saving and Emission-Reduction(ESER).
\end{abstract}

Keywords-energy saving and emission reduction; wide caliber training;professional platform; curriculum system reform; model of characteristic curriculum system

\section{INTRODUCTION}

Along with the quick development of the social economy, how to solve the problem of energy shortage and environmental change has been very urgent. In order to make economy development continue, global people of insight are advocating and promoting Energy-Saving and Emission Reduction (ESER) [1].

But ESER is an arduous task and one's road long, and desiderates high level technical talents. Colleges and universities are the important bases of training high level technical talents. They must shoulder the task to cultivate ESER talents. As the energy specialty closely related to ESER must walk in the forefront of cultivating ESER talents.

On the other hand, with the development of the society, the talents are requested higher, the competition in the talent market is more intense. In order to gain a place in the talent competition market [2], Colleges and universities must adjust the specialty structure, innovate training model and set up a professional platform on which cultivated talents can be accepted by the market, are capable of performing a variety of occupations, have better self-regulating ability.

In this paper, on the basis of the analysis of talent market prospects for ESER and personnel-training strategies, taking our heat and power-engineering specialty for example, we explored to build a curriculum system adapted to personneltraining. The results are tried to apply to train composite and applied talents who are not only with the ideas and knowledge structure of ESER, but also are with a wide adaptability and distinctive feature. And the results can also be used for reference by relevant specialty in the personneltraining.

\section{NECESSITY OF ESTABLISHING PERSONNEL-TRAINING MODEL WITH CHARACTERISTICS AND WIDE CALIBER}

Under the background of the arrival of low carbon economy, with the further development of economic globalization, the national strength competition becomes increasingly fierce. To achieve the fast and sustainable development, China needs a large number of talents who have the concept and knowledge structure of ESER. It has strategic significance to do education to the students in colleges and universities, which is also an effective safeguard of sustainable development of national energy and economy [3].

This will no doubt play an important positive role to meet the social demand, to improve the overall quality of the Chinese nation, to expand the scale of recruit students and to achieve the change from elite education to popular education in higher education. However, with the expansion of the scale of recruit students, due to the restriction of imbalance of economic growth, higher education development and social demand, the contradiction of employment has highlighted. The employment situation of colleges and universities students has become increasingly more severe, they are facing the unprecedented pressure of employment. Employment has become one of the outstanding problems of higher education facing in China, which is one of the hotspots for the current society. Colleges and universities are the bases of training senior talents, the students trained must have the ability to service the society, must be able to meet the society needs. Therefore, to some different extent, the modern higher education constantly increases the market factors, and takes part in the operation of the market. Under the background of increasing recruit students and realizing popular education and difficult employment, if the colleges and universities don't have their own characteristics and advantages, it is difficult to foothold in competition of personnel-training. The personnel-training quality and characteristics are the key factor of the measure of competitiveness of higher education.

In 30 years of reform and opening up, the personneltraining goal in the undergraduate of China's colleges and universities has changed from cultivating "red and expert" to cultivate "thick foundation, broad caliber". The results have 
both advantageous side and the disadvantageous side. The advantageous side is, to a certain extent, to meet the market economy needs and personal development; the disadvantageous side is the structural imbalance of the talent supply. There is a contradiction between the "thick foundation and broad caliber" target and the professional talent requirements. It is not suitable for directly facing the talent employment market. Therefore, the different colleges and universities and their specialties must have the diversity objective orientation of personnel-training [4], and must establish a personnel training professional platform which is suitable for their own conditions, characteristics and has competitiveness and accords with the ESER personnel training.

\section{DIFFICULTIES AND SOLUTION WAY TO SET UP A WIDE CALIBER CHARACTERISTIC PERSONNEL-TRAINING MODEL}

It is one of the important tasks of higher education reform to broaden the professional caliber and to cultivate high-quality talents with wide adaptability, which is undoubtedly very necessary.

Existing main contradictions have the following several aspects [5]:

(1) The contradiction between the rapidity and diversity of the society need change and the relative stability and lag of the university personnel training.

(2) The contradiction between the particularity of the social demand for talents and the generality of personnel training in colleges and universities.

(3) The contradiction between the universality of work employment and technicality of personnel training in colleges and universities.

From the point of view of the student employment, on the one hand, the wide caliber training model is conducive to increase students' employment range, but on the other hand, the employer wants students as professional as possible. How to resolve this conflict became the focus problem of plaguing colleges and universities training personnel.

The goal of institutions of higher learning training personnel is to provide a variety of talents for the country's construction in the final analysis. It is also to make our country create a strong competitive power under the conditions of the integration with the global economy. Colleges and universities have to face the industry to run a school, but not like the original to face a single industry to run school. They should face a variety of industries in a field to run school, which requires a wide caliber teaching. But at the same time, they must pay attention to prevent overstating the significance of the "general knowledge" education and to prevent wishful thinking that can realize. We can actually not reach the so-called "generalist" culture at all. The results disjoint the personnel training and industry demand, make the pertinence of the personnel-training and scientificresearch weakened greatly, and make the function for the industry development to provide personnel-resource and technology-support weakened greatly too. This will not only affect student employment, is also bound to seriously affect the competitiveness of higher education institutions, and affect their development and even survival.
To solve these problems, we should focus on the following tasks:

(1) make a difference between, look for exact location

For high level key universities, their professional-caliber of personnel-training can be wider than some, which can lay a good foundation not only for students entering in graduate learning, but also open up wider avenues of employment for their students, due to their reputation advantage.

For the general colleges and universities of relatively lower level, the range widen professional caliber in personnel training should be smaller. At the same time to properly expand professional caliber, they should mainly consider professional counterparts to strengthen the applied professional knowledge education, to make employment of graduates be able to task as soon as possible.

In a word, professional position orientation relates to the success or failure of personnel-training. The professional position orientation should be accurate, characteristic, cannot machine-made, which should form a complete scientific system.

(2) Taking various training model to achieve the diversification of training objectives

From the talent society demand, the society needs both research talents, technical talents and complex talents.

From the higher education itself, higher education form is varied, its types are various. This diversity express as the diversity of training goal, the diversity of quality standards, diversity of training model and so on.

The diversity of the training goal conduce to the accurately positioning the target. Various kinds of training targets of research, technology, composite, etc have obvious difference. We should adopt different training model to achieve them. Thus, according to different personnel-training goals to take different training model, we both can fully meet the society need diversification and can realize the training goal diversification. This is very important for the formation of the characteristics and improvement of the personneltraining competitiveness in the colleges and universities.

\section{CURRICULUM MODEL TO ENSURING CHARACTERISTIC PERSONNEL-TRAINING}

\section{A. Necessity, Problems and Solutions of Characteristic Personnel-Training Curriculum System}

Scientific and effective curriculum system is an important foundation and necessary conditions for personnel-training in colleges and universities. This is also an important content of the higher education reform.

The curriculum system supports this goal. That is a wide caliber professional platform curriculum system. The establishment of the curriculum system of the professional platform is the emphasis and difficulty of this reform. This is because the wide caliber professional platforms curriculum system must cover the main content of a few original specialties. Therefore the curriculum system of the wide caliber professional platform should not only cover the contents of the original specialties, and must not be built into 
a "cold dish" of a several original professional contents. Obviously, under premise of not increasing hour, it is very difficult. Whether the professional platform curriculum system can be established successfully has a great influence to the success or failure of the higher education reform. Therefore, the built platforms curriculum is not a simple superposition of the amount of original several directions, and must have a qualitative leap. The realization of the teaching class aims can't just rely on the platform class itself. In other words, the establishment of professional platform curriculum system can not be undertaken in isolation, must set up corresponding guarantee system. It should be done with the overall curriculum system reform, teaching method reform, teaching material construction and the school supporting mechanism reform.

\section{B. Unit Construction of Characteristic Curriculum Model to Ensure Personnel Training Platform}

It is very necessary to broaden the professional caliber, to reflect the characteristics, to form strong personnel-training competitive power. Scientific and effective curriculum system is an important foundation and necessary conditions for characteristic personnel training in colleges and universities. And it is very important to establish the model of the corresponding curriculum system. We think that should be the following aspects [6]:

1) Broadening Professional Caliber and Insisting Characteristics Simultaneously to Establish Professional Platform Curriculum System:To broaden the professional caliber to enlarge students' knowledge can laid the personnel-training foundation. It plays an important role to adhere to the professional characteristic education to improve the students' social and international competitiveness.

In order to effectively broaden the specialty caliber, we must set up a series of courses covering a wide various original professional contents related, which is the so-called professional platform curriculum system. In the curriculum setting, different schools should base on their own development history, advantages and the actual situation to establish their own professional platform curriculum system which can reflect their own features and advantages.

In the content selection, the curriculum system cannot be completed for simple "cold dish" of several professional content related, must have a qualitative leap. It not only is able to broaden the professional caliber, and is different with other colleges and universities. It should reflect the special features of oneself. It can closely relate to the social demand, can stand in the forefront of development of the industry and ECER [7].

2) Outstanding Characteristics, to Establish and Perfect Professional Direction Curriculum System

a) Establishing and expanding professional direction lesson modules,To embody the professional direction features: In order to meet the demands of the society for talents and to create conditions to improve students' wide adaptability, the establishment of the professional model should meet all sorts of needs of personnel training. Curriculum system related to form a relatively perfect professional module, so that the students can systematically grasp the professional knowledge of the professional direction.

In order to adapt to the scale of the school, and full play to the role of school resources, combining with talent needs of the market and actual condition of the school, we adjusted and developed the professional direction to improve the education system, and maintained curriculum system characteristics. But we don't go in for grandiose projects unrealistically, in order to ensure the quality of personnel training.

b) With the direction elective courses to promote the development of the student's personality: Elective courses of relevant areas are offered for students. Students can take their favorite elective course according to their interests and career planning. This can promote students' individual character development.

3) With practical teaching, auxiliary theoretical teaching, improving students' ability to innovate:It is an important task for education reform to enhance cultivation of students' ability and to improve the quality of students. Practical teaching links can make students' ability improved greatly. In the teaching plan, the hours and contents of practice teaching should be appropriately increased. for example, the practice teaching and its specific gravity of the curriculum design, internships, graduation design, computer applications, and innovative skills training should be increased, Which can increase the depth for students' understand knowledge and improve their ability to apply knowledge to solve practical problems. This is also helpful for auxiliary the teaching effect of professional platform course and related course. Practical teaching links and theoretical teaching are supplement each other. The Students' practical application ability and innovation ability, in the very great degree, is closely related with practical teaching course system. The Practical teaching link will play great, irreplaceable role in the whole personnel-training of application ability and innovation ability.

4) The curriculum system interconnected, Complement each other:Curriculum system and state policies are closely linked. The courses are complete system which is interconnected and mutually reinforced.

It is very difficult to make the basic course, the platform class, the direction class and the specialized elective course form bright features. The prominent contradictions are between broadening the specialty range and improving the effect of training application ability. Within a very limited class, it is not possible to well-rounded teach everything. But this does not mean that you can reduce the quality of teaching. The starting point of higher education reform is to realize the change from the simple imparting knowledge to not only imparting knowledge, and increasing the ability, improving the quality. This will no doubt greatly increase the 
teaching difficulty. To solve this problem, we must first integrate the contents in multi-dimensional, make the course system scientific, make each part of it closely interconnected inter-permeated, supplemented each other. At the same time, the idea of teachers must also be changed; the construction of teachers' team must be strengthened; the lack of textbooks should be solved; the teaching methods should be reformed; the teaching facilities should be increased and improved, etc.

And the completion of these jobs has the considerable difficulty, some still need to research and explore. Therefore, the establishment of characteristic course system must not be isolated, must progress with other reform of higher education.

\section{SUMMARY}

ESER, the development of recycling economy is the only way to achieve the sustainable development of Chinese economy. on the one hand, ESER urgently need these talents, On the other hand, ESER may make a considerable part of industries shut down and cause structural unemployment.

Under the big background of enlarging enrollment to realize higher education popularization and difficult employment, colleges and universities, in particular, the general colleges and universities want to have a place in the university's competition with numerous strong competitors. They must establish and perfect the distinctive course system, which relates to the survival and development of them. In the personnel training of energy kind of specialty, through research and exploration on the curriculum system which has a distinctive features and can meet the demand of ESER to establish professional personnel-training platform will help to improve the competitiveness of professional personnel training.

Of course, the difficulty of operating the course system is greater. Improvement of application effect still needs a lot of work to do. We believe that, with the continuous deepening of the higher education reform and establishment of scientific operation mechanism, perfect characteristic curriculum system will play an important role in the personnel-training competition in higher education for the realization of the training objective.

\section{ACKNOWLEDGMENT}

This work was supported by Heilongjiang Association of Higher Education (HGJXH B1110521) and Harbin University of Science and Technology. To express gratitude to them, at one time, to give thanks to other colleagues of our Department of Thermal Energy and Power Engineering who give us a hand.

\section{REFERENCES}

[1] Juan Liang,Huaqiang Yin,Jiaxiu Guo,Faming Liao.Thinking about Low-Carbon Utilization of High-carbon Energy Resourcees in China [C]. Collected Ppapers of Forum on the Second China Energy Scientist.USA:Scientific Research Publishing, 2010,pp891-892.

[2] Qisheng Liu,Bingbing Yan,Guangjun Chen. Inquiry of the engineering application talents trainingIn order to enhance the employment competitiveness as the goal. China power education [J]. 2011 (14).

[3] Xuedong Mao, Sijiang Ao.Theoretical Analysis and Discussion of Low-Carbon Campus Construction and Its Ways in Colleges and Universities. Collected Ppapers of Forum on the Second China Energy Scientist.USA:Scientific Research Publishing, 2010,pp10341035.

[4] Junxing Cao,Xiaoliang Cheng,Aizhen Sun,Liang Zhao,Mei Huang. Since thirty years of reform and opening up, the evolution and reflection of the undergraduate education training target [J]. Journal of chengdu university of technology (social science edition). 2008 (4) ,pp 29-32.

[5] Bo Qu, Tuo Liu. Construction of Characteristic specialty and innovation of talent cultivation system [J]. China's higher education. 2008 (15)

[6] Xingjia LIU,Jiuru LI,Wei LV,Zuomin WANG,Mingqi SUN. Research on Curriculum System to Adapt to Demand of Energy Saving and Emission Reduction. The 2nd Theaching Seminars on Higher Education Science and Engineering. Scientific Research Publishing,USA,2012.11.

[7] Xingjia Liu. Higher education reform and the construction of professional platform class some thinking [J]. impart knowledge and educate people. 2001 (5) 